\title{
Human Resource Management Practices Aimed at Seeking the Commitment of Employees on Financial and Non-Financial (Subjective) Performance in Spanish Firms: An Empirical Contribution
}

\section{Prácticas de la Gerencia de Recursos Humanos dirigida a buscar el compromiso de los empleados en el desempeño organizacional financiero \\ y no-financiero (subjetivo) en empresas españolas: \\ una contribución empírica}

\author{
Rafael Triguero 1 \\ Jesús Peña-Vinces ${ }^{2}$ \\ Manuel González-Rendon3 \\ Mercedes Sánchez-Apellaniz ${ }^{4}$
}

Received: October 18, 2011

Accepted: February 01, 2012

\begin{abstract}
The purpose of this paper is to assess the relationship between Human Resource Management (HRM) practices and organizational performance in Spanish firms from a financial and non-financial perspective (subjective). The empirical study was conducted with a sample of 102 firms in the region of Andalucía (Spain). The results of statistical analysis have shown the fundamental role of establishing HRM practices aimed at seeking the employees' commitment and its positive influence on organizational performance. Results also showed that the subjective measures for organizational performance better explained this phenomenon of study.
\end{abstract}

Keywords: HRM practices, employees' commitment, financial performance, non-financial performance (subjective performance).

1. PhD. in Human Resources Management, Investigador de la Facultad de Ciencias Económicas y Empresariales, Dpto. de Administración de Empresas y Marketing de la Universidad de Sevilla.<rtriguero@us.es>.

2. PhD. in Economics and Business, Profesor/Investigador Facultad de Ciencias Económicas y Empresariales, Dpto. de Administración de Empresas y Marketing de la Universidad de Sevilla.<jesuspvinces@us.es>.

3. PhD. in Economics and Business, Catedrático de Facultad de Ciencias Económicas y Empresariales, Dpto. de Administración de Empresas y Marketing de la Universidad de Sevilla. <rendon@us.es>.

4. PhD. In Economics and Business, Profesora Titular Facultad de Ciencias Económicas y Empresariales, Dpto. de Administración de Empresas y Marketing de la Universidad de Sevilla.<apellaniz@us.es>. 


\section{Resumen}

El propósito de este artículo es evaluar la relación entre las prácticas de la Gerencia de Recursos Humanos (HRM por sus siglas en inglés) y el desempeño organizacional en firmas españolas desde la perspectiva financiera y no financiera (subjetiva). Este estudio empírico fue realizado con una muestra de 102 firmas en la región de Andalucía (España). Los resultados del análisis estadístico demuestran el rol fundamental de establecer prácticas de HRM dirigidas a buscar el compromiso de los empleados y su influencia positiva en el desempeño organizacional. Los resultados también indican que las medidas subjetivas para el desempeño organizacional explican mejor este fenómeno en investigación.

Palabras clave: Prácticas HRM (Human Resources Management), compromiso de los empleados, desempeño financiero, desempeño no financiero (desempeño subjetivo). 


\section{INTRODUCTION}

In recent years a number of studies related to the association between Human Resource Management (HRM) practices and the level of employees' commitment and business results have been published. This association has strengthened its role as a source of competitive advantage (Barney \& Wright, 1998; Guthrie, 2001; Martin, Romero \& Gardey, 2006). However, the differences obtained in those studies seemed to suggest the existence of contextual and cultural variables that might impact organizational performance (Guest, Michie \& Conway, 2003; Richard, Murthi \& Ismail, 2007). The vast majority of these studies have been conducted in countries such as the USA, UK, Korea, Japan, Taiwan, etc. However, none have been conducted in Spain. Therefore, this study attempts to fill this gap in the existent literature by testing the relationship between HRM practices aimed to foster employees' commitment as well as organizational performance in the southern region of Spain.

Currently more than half of the Spanish firms follow an isomorphism approach. In other words, these companies tend to imitate or copy the HRM practices from other businesses, but the truth is that they are not aware of how it affects its organizational performance. In this sense, our investigation is presented as an alternative to this problem.

Some researchers have discussed the suitability of using financial measures (FM) and non-financial measures (NFM, broadly known as subjective), for the measurement of organizational performance (Bontis, Hulland \& Crossan 2002; González, Correa \& Acosta, 2002; Zou \& Stan, 1998). For the financial measures, there are indicators such as ROA (Return on Assets) which shows how profitable a company is in relation to its total assets, and ROS (Return on Sales), both associated to the operating margin of the firm. These measures are widely accepted from the accountancy sciences point of view; however, they do not adequately satisfy the needs in other fields of research (Eccles, 2004; Naranjo-Gil \& Álvarez-Dadet, 2006).

For instance, the non-financial measures (subjective) indicators, such as the perception that employees and managers have on the performance of their organiza- tions, are usually used. It is worth mentioning that this type of organizational performance is perceived with caution by some researchers who have a preference for purely accountable information systems. This does not seem to agree with the broad acceptance this indicator is having among researchers within the field of business administration (Hartmann, Naranjo \& Roldán, 2005; Real, Leal \& Roldán, 2006; Yacuzzi, 2010).

Our study has been structured as follows: first, a literature review is provided which allows the building of the research model and the posing of two hypotheses. Second, the methodology and testing the hypotheses is provided. The final part offers the findings and implications of the study.

\section{BACKGROUND AND DEVELOPMENT OF THE RESEARCH MODEL}

Human Resource Management (HRM) practices affect organizational performance through their effect on employee development and behaviors. These practices determine the type of employees who are selected, the skills and motivation of the employees, and the opportunities and incentives they have to design new and better ways of doing their jobs (Moideenkutty, AlLamki, \& Rama Murthy, 2011). The common theme in the literature that relates management of human resources with business results sets the emphasis in the use of systems that can make the achievement of a source of competitive advantage possible. (Guthrie, 2001). In this sense, HRM practices could be a good system by which to provide a competitive advantage.

From a "Contingent Approach", HRM practices focus more on employees' commitment than on mere compliance (Alcazar, Fernández \& Gardey, 2005). With the high costs involved in employee selection and recruitment, companies are increasingly concerned with retaining employees. Generating employees' commitment is an important consideration for both large and small organizations. (Shahnawaz \& Juyal, 2006).

The contingent approach analyzes HRM practices from two perspectives. On the one hand, those practices could be oriented to obtain a better employee commitment with the organization (Collins \& Smith, 2006). 
On the other hand, HRM practices could also search for the control of its employees (Gooderham, Parry \& Ringdal, 2008; Guest, Michie, \& Conway, 2003). The latter is normally associated with the direct and lineal performance of employees (Arthur, 1994).

When measuring organizational performance, HRM practices expose two approaches. First, we find studies that assess performance from a purely "financial" perspective, using variables such as business profits, units produced, average sales per employee, ROI, ROA, ROS, and so forth (Dalrymple, 2004; Goll, Brown \& Rasheed, 2008). And, from a non-financial perspective (subjective), studies have focused on the "perceived performance" of employees and/or directors, in regards to its competitors and industry (Bontis, Hulland \& Crossan, 2002; Nonaka, 1994, Real, Leal \& Roldán, 2006) In this sense, research studies have shown clear links between HRM practices and organizational performance (Aycan, 2005; Bamberger \& Meshoulam, 2000; Basset-Jones, 2005; Martin, Romero \& Gardey, 2006; Moideenkutty Al-Lamki, \& Rama Murthy, 2011; Shahnawaz \& Juyal, 2006).

The literature review, previously outlined, provides evidence of whether the two measures (financial and subjective) will have positive effects on HRM practices. To explore if such relationship exists among the studied companies, specifically in the Spanish firms, we propose the following hypotheses:
Hypothesis 1: The financial performance will be found positively conditioned by HRM practices aimed to foster employees' commitment.

Hypothesis 2: The subjective performance will be found positively conditioned by HRM practices aimed to foster employees' commitment.

Once the literature is described and the theoretical framework is developed, the hypotheses are collected and graphically represented in the model of investigation (Figure 1) where the assessments will be developed through Structural Equations Models (SEM), particularly with the PLS technique.

\section{METHODOLOGY}

\section{Population and sample description}

The questionnaire methodology was adopted in this work (Barroso, Cepeda \& Roldán, 2010; Real, Leal \& Roldán, 2006) according to the approaches suggested by Dess \& Davis (1984) for investigation of human resources management. Concerning the unit sample, the questionnaires have been answered by managers of HR, Chair of HR and general directors.

The indicated people in each company were telephoned to thoroughly explain the importance of taking part in the study and also of its usefulness. If

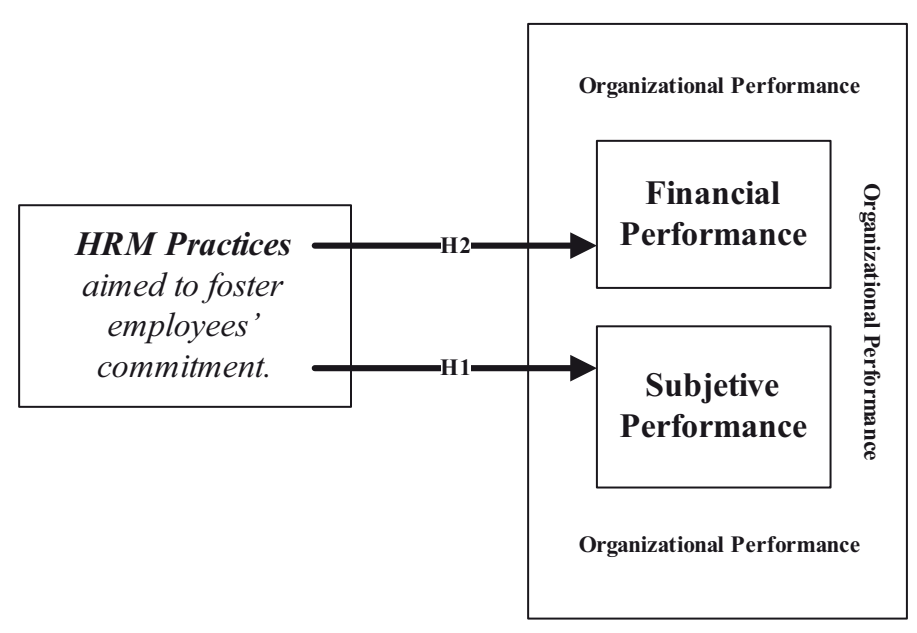

Figure 1. Research model. 
requested, we pledged sending them the results of the research. The participants were also assured that the information would be dealt globally, confidentially and anonymously. Finally, we highlighted the importance of the suggestions that the interviewees proposed to us, and our gratitude regarding their participation. All of these aspects were emphasized in the introductory letter, which was subsequently forwarded together with the questionnaire and a prepaid envelope for returning the questionnaire upon completion.

The companies were selected from the SABI database (Iberian Balances Analysis System). Among the registered companies, 1,300 had between 100 and 2,000 employees, according to the data registered in 2007 , and 1,169 were established before 2003. The resulting population was 902 with a well-balanced representation of all productive sectors. A total of 103 questionnaires were returned in different forms: via email, postal mail, on-line survey (web survey) and personal interviews within the organizations. The response represented a $11.42 \%$ reply rate. In regards to the character of the companies, $93 \%$ of them belonged to the private sector, and the remaining were from the public sector, that is, the Spanish government. The following tables (Table 1 and 2) summarize the descriptive statistics of the unit analysis.

\section{Measures}

Literature was consulted in order to obtain a reliable measurement, using tools broadly validated and contrasted in previous research studies. The items adapted from English literature were translated from English into Spanish by two native Spanish speakers who are familiar with the terminology on HRM in order to avoid any ambiguity in the measurement scales.

Table 1.

Survey Technical Data

\begin{tabular}{ll}
\hline Population size & 902 Firms \\
Universe & Manager of HR, Chair of HR, and CEO. \\
Place of Study & Andalucía (Spain) \\
$\begin{array}{l}\text { Sampling method } \\
\text { de la información }\end{array}$ & Survey: via e-mail, postal survey, and personal interviews \\
Sample size & 102 surveys (discounting one ineligible and incomplete) \\
Time period & June 2009 to October 2009 \\
\hline
\end{tabular}

Table 2.

Sample's Descriptive Statistics

\begin{tabular}{lccccc}
\hline \multicolumn{1}{c}{ Characteristics } & $\mathrm{N}$ & Minimum & Maximum & Mean & SD \\
\hline Years of operations & 97 & 7 & 86 & 20.90 & 12.28 \\
Number of employees & 102 & 30 & 1.72 & 218.03 & 265.59 \\
Total Assets (last three years) in Euros (€) & 102 & 327393 & 416598667 & 37051984 & 65657472 \\
Business membership (Private) & 102 & 0 & 1 & 0.93 & 0.25 \\
Manager's HR department & 102 & 0 & 1 & 0.68 & 0.47 \\
Gender Male & 102 & 0 & 1 & 0.66 & 0.25 \\
\hline
\end{tabular}

Note: SD. Standard deviation N=it referred to the number of firms 
The variables used to measure HRM practices are supported in the existing literature using Guest, Michie \& Conway (2003) measuring items, with a 1-7 Likert-type scale. In this sense, Figure 1 indicates high control \& little commitment in the organization and figure 7 denotes high commitment and little control. In this variable, aspects such as personnel selection, training, evaluation, wage flexibility, job design, level of communication, job stability, equal opportunities and the quality of human resource management have been measured. These aspects allowed us to see the orientation of human resources strategies used by the companies studied according to Guest, Michie \& Conway (2003) (see the complete scale in the Appendix).

To measure the subjective performance, the Bontis, Hulland \& Crossan (2002) measurement scale was used. Therefore, the performance has been measured both at the individual and group level, as well as for the whole organization, following Nonaka's (1994) theoretical proposal. It is important to mention that this measurement scale has become very popular among Spanish academics (Real, Leal \& Roldán, 2006). When measuring organizational performance, for the financial performance case, we used measures widely accepted by the academic community, specifically, the famous financial accounting measures, such as ROA and ROS, used by Boone et al. (2004) and Carpenter (2002) (using the mean of the last three years).

According to the revised literature regarding the measurement of organizational performance, almost $100 \%$ of the studies have always used control variables based on two important grounds. First, the objective is to obtain a "parsimonious model" (Mesquita \& Lazzarini, 2008) and, second, performance in an organization depends on multiple factors or areas of the company. Therefore, the following measurement items were used: 1) the size of the enterprise, measured by the number of employees working in the firm (Carpenter, 2002; González \& Denisi, 2009); 2) the industrial sector, broadly used as a control variable (Giardini \& Kabst, 2008) and which has followed the classification offered by the National Institute of Statistics in Spain (NIS) that ranks productive sectors into agriculture, industry, construction, trade and restoration, transportation and communications, business services and other services.

\section{DATA ANALYSIS, RESULTS, AND TESTING OF THE HYPOTHESES}

At this stage of the research study, the information was analyzed through the Structural Equations Model (SEM) specifically through the PLS (Parts Least Square) technique (Chin, 2003) that consists in the evaluation of a SEM in two stages. First, the measurement model was evaluated, allowing the assessment of non-observable variables and non-specified theoretical concepts. In the second phase, the evaluation was for the structural model that deals with the consistency of the relations of the model with the theory used (Barroso, Cepeda \& Roldán, 2010). The PLS procedure has gained interest and has been used among researchers in recent years because of its ability to model latent constructs under conditions of non-normality and with small to medium size samples (Barroso, Cepeda \& Roldán, 2010; Chin, 1998; Real, Leal \& Roldán, 2006), thus, the main reason for choosing this statistical technique. This method, which uses the Ordinary Least Squares (OLS) algorithm, has been designed to reflect the theoretical and empirical qualities of social sciences and its behavior in situations with insufficient supported theories and little available information (Chin, 1998; Real, Leal \& Roldán, 2006).

Our model of investigation is composed of four constructs; two of them are of second order (HRMp and SP). Once second order constructs have been transformed into first order constructs and included within the model, it was necessary to differentiate between reflective (HRMp, SP and FP) and formative constructs (CV) since both constructs have different statistical treatments (Barroso, Cepeda \& Roldán, 2010; Chin, 2003).

The data obtained in our study (Table 3 ), in regards to the formative constructs has no-multi-collinearity problems since their values are well below the limit of 3.30 established by Roberts \& Thatcher (2009) [Variance Inflation Factor (VIF), VIF $\leq 3.30$ ]. The reliability analysis of the items for reflective constructs, according to Table 3 , shows values $>0.707$ as stated by Nunnally (1978).

The next step, within the evaluation process of the measurement model (first step), is the convergent validity analysis, obtained through the Average Variance 
Extracted (AVE) (Barclay, Higgins \& Thompson, 1995; Barroso, Cepeda \& Roldán, 2010). Fornell \& Larcker (1981) recommend an average variance extracted greater than 0.50 because, in that sense, it can be established that more than $50 \%$ of the variance of the construct is due to its indicators. According to the values shown in Table 3, the model records adequate values; they never fall below $59 \%$. And, as an additional evaluation, the assessment of the discriminant validity of the construct has been analyzed (Barroso, Cepeda \& Roldán, 2010). In this first stage of the evaluation of the measurement model (MM), the discriminant validity indicates as to what extent a given construct is different from other constructs. As shown in Table 4, the correlations between the constructs are lower than the square root of the average variance extracted (AVE).

Table 3.

Results of Measure Model of SEM

\begin{tabular}{|c|c|c|c|c|}
\hline \multicolumn{5}{|l|}{ FORMATIVE CONSTRUCTS } \\
\hline \multicolumn{5}{|l|}{ Control variables $(\mathrm{CV})$} \\
\hline Items & Tolerance & FIV & FIV & T-Values \\
\hline Number of employees & 0.972 & 1.03 & 0.989 & $4.573 * * *$ \\
\hline Industrial sector & 0.972 & 1.03 & -0.388 & 0.799 \\
\hline \multicolumn{5}{|l|}{ REFLECTIVE CONSTRUCTS } \\
\hline & Loading & $\mathrm{CR}$ & AVE & T-Values \\
\hline Financial performance (FP) & & 0.892 & 0.805 & \\
\hline$R O A$ & 0.889 & & & $12.462 * * *$ \\
\hline$R O S$ & 0.905 & & & $15.640 * * *$ \\
\hline Subjective performance (SP) & & 0.883 & 0.715 & \\
\hline Individual performance & 0.908 & & & $64.234 * * *$ \\
\hline Group performance & 0.813 & & & $26.243 * * *$ \\
\hline Organizational performance & 0.813 & & & $18.623 * * *$ \\
\hline HRM practices (HRMp) & & 0.923 & 0.590 & \\
\hline Selection & 0.717 & & & $13.902 * * *$ \\
\hline Training & 0.832 & & & $28.474 * * *$ \\
\hline Evaluation & 0.766 & & & $19.227 * * *$ \\
\hline Flexible remuneration & 0.751 & & & $19.700 * * *$ \\
\hline Job design & 0.897 & & & $45.383 * * *$ \\
\hline Bidirectional communication & 0.799 & & & $18.774 * * *$ \\
\hline Job stability & 0.818 & & & $21.047 * * *$ \\
\hline Equality & 0.894 & & & $42.726 * * *$ \\
\hline Job quality & 0.945 & & & $98.654 * * *$ \\
\hline
\end{tabular}

Note: CR: composite reliability AVE: Average variance extracted. FIV: Variance Inflation Factor

Table 4.

Descriptive Statistics, Correlation Matrix and the Discriminant Validity

\begin{tabular}{lrrrrrr}
\hline & Mean & \multicolumn{1}{c}{ SD } & FP & VC & SP & HRMp \\
\hline FP & 10.368 & 31.501 & 0.944 & & & \\
VC & 7.619 & 3.483 & -0.173 & N/A & & \\
SP & 5.437 & 0.861 & 0.246 & 0.009 & 0.940 & \\
HRMp & 4.052 & 1.249 & 0.199 & 0.025 & 0.694 & 0.975 \\
\hline
\end{tabular}

Note: Mean, the average score for all items included in this measure, SD. Standard deviation. Diagonal elements are the square root of the variance shared between the constructs and their measures. Off-diagonal elements are the correlations among constructs. For discriminant validity, diagonal elements should be larger than off-diagonal. Significant $=* \mathrm{p}<.05 ; * * \mathrm{~N} / \mathrm{A}=$ not applicable. 
Once the validity and reliability of the measurement model have been demonstrated, it has been valued whether or not the structural model supports the proposed research model (2nd stage); that is to say, the existing relations between the latent variables according to the theory used as a base for constructing such model are evaluated (Chin, 2003). The model was tested considering the intensity of path coefficients or standardized regression weights and the explained variance $\left(\mathrm{R}^{2}\right)$ of the endogenous or dependent variables. On the other hand, the "Bootstrap" nonparametric technique was applied to evaluate the accuracy and stability of the estimates obtained that exposes the significance of the structural paths, which, in turn, gives the opportunity to support the proposed hypotheses through the standard error and the T-Student values of the model (Barroso, Cepeda \& Roldán, 2010; Chin, 2003).
Additionally, the predictive relevance was evaluated through Q2 (Geisser, 1974; Stone, 1974), exceeding the requirement of $\mathrm{Q}^{2}$ greater than zero $\left(\mathrm{Q}^{2}>0.00\right)$. Finally, the results confirm that the structural model has predictive quality, obtaining a GOF (Goodness - of - Fit) away from zero and close to one (Tenenhaus, 2008) (see Table 5 and Figure 2).

\section{DISCUSSION OF RESULTS}

The confirmed hypotheses have shown the strategic character of HRM and its impact in both financial and subjective performance. The results of our SEM (Figure 2) reveal the positive effects between the orientation of HRM practices searching for employees' commitment and the perception that managers have

Table 5.

Values of Structural Model

\begin{tabular}{cccccrc}
\hline \multicolumn{2}{c}{ Hypotheses } & Support & Path (T-values) & Direct effects (\%) & $\mathrm{R}^{2} \%$ & $\mathrm{Q}^{2} \%$ \\
\hline $\mathrm{H} 1$ & $\mathrm{HRMp} \rightarrow \mathrm{FP}$ & Yes & $0.696\left(13.530^{* * *}\right)$ & 33.69 & $48 \%$ & $18 \%$ \\
$\mathrm{H} 2$ & $\mathrm{HRMp} \rightarrow \mathrm{SP}$ & Yes & $0.199\left(2.115^{*}\right)$ & 1.41 & $7 \%$ & $27 \%$ \\
& $\mathrm{CV} \rightarrow \mathrm{FP}$ & No & $-0.173(1.722, \mathrm{~ns})$ & & & \\
& $\mathrm{CV} \rightarrow \mathrm{SP}$ & No & $-0.009(0.128, \mathrm{~ns})$ & & & \\
\hline
\end{tabular}

Note: $\mathrm{N}=1000$ subsamples $\uparrow \mathrm{p}<.1 * \mathrm{p}<.05 * * \mathrm{p}<.01 * * * \mathrm{p}<.001 \quad(.1 ; 999)=1.282 \uparrow \mathrm{T}(.05 ; 999)=1.646 * \quad \mathrm{~T}(.01 ; 999)=2.330 * *$ $\mathrm{T}(.001 ; 999)=3.098 * * * . \mathrm{Ns}=$ None supported.

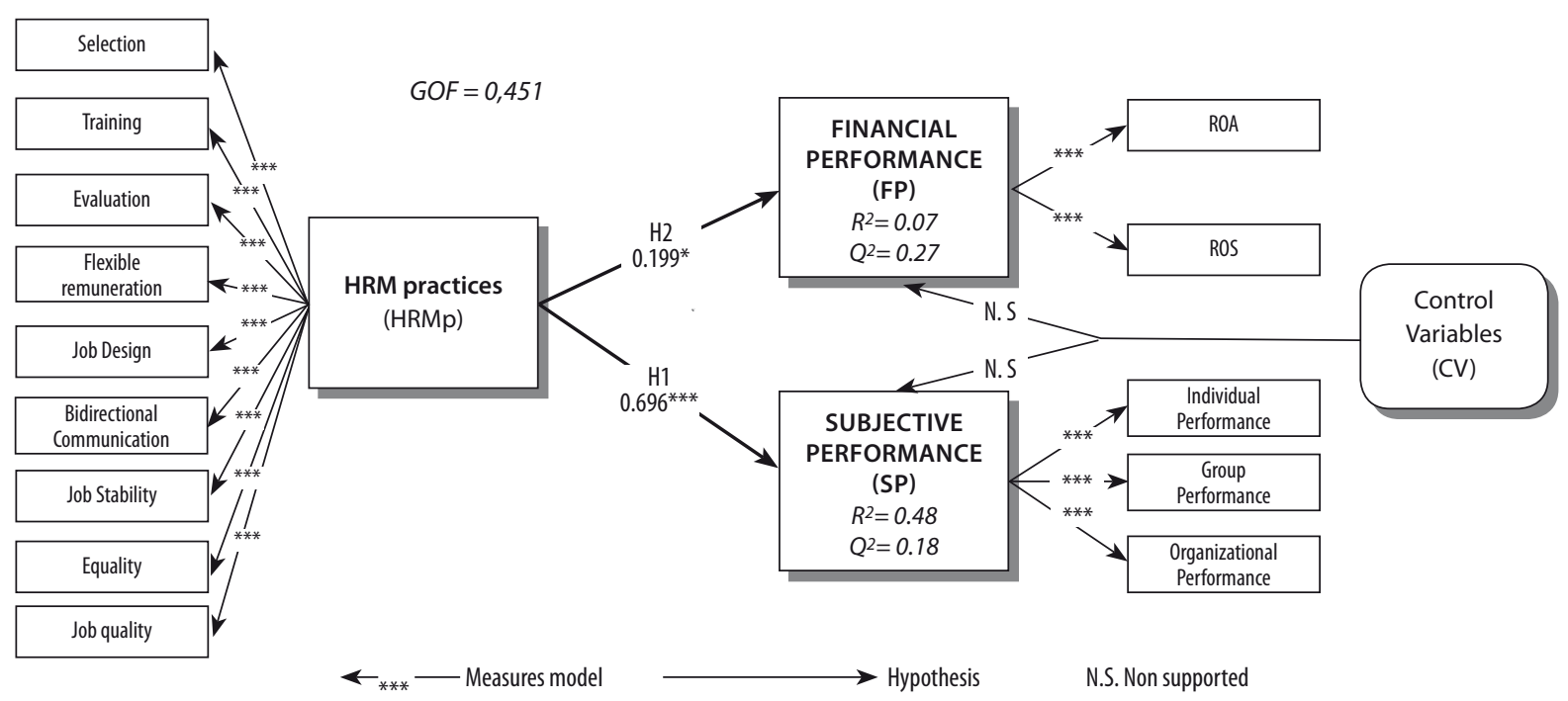

Figure 2. Results of the SEM. 
of the subjective performance $(\beta=0.696 ; p<.001)$, as well as of the financial performance $(\beta=0.199 ; p<.1)$, although in this last case with a weaker relationship. The control variables have not been supported in our model; however, we justify their inclusion because they allow for greater control of the phenomenon studied (Mesquita \& Lazzarini, 2005).

The model graphically shows that the biggest value of explained variance $\left(\mathrm{R}^{2}\right)$ in our independent variable has a strong relation with the subjective performance $\left(\mathrm{R}^{2}=0.48\right)$. But, when analyzing the financial performance, the variance shows lower values $\left(\mathrm{R}^{2}=0.07\right)$. In this respect, data seem to suggest that when studying HRM practices in relation to organizational performance, the key role that subjective performance measures play for the explanation of this type of phenomena should be considered. Also, this affirmation can be confirmed when analyzing the predictive quality of the independents variables. In our case, the subjective performance $(\beta=0.696)$ has a more predictive quality than the financial performance $(\beta=0.199)$.

\section{CONCLUSIONS AND IMPLICATIONS}

The data obtained showed that human resources policies and practices followed by the Spanish firms have positive effects on organizational performance (subjective and financial), when they pursue the achievement of employees' commitment. In fact, such results have had the same positive effects for both, subjective and financial performance according to prior investigations (Moideenkutty, Al-Lamki \& Rama Murthy, 2011; Shahnawaz \& Juyal, 2006; Yacuzzi, 2010). Those results point out the existence of benefits derived from the use of an integral measurement system (financial and subjective) capable of overcoming any difficulties that might arise during its implementation.

On the other hand, all HRM practices analyzed in this study have shown positive effects on organizational performance, but with special impact on those related to job quality; hence the existence of quality management programs, the involvement of employees in problem-solving and decision making in the organization, the implementation of quality circles, the building of better work teams and to a large extent, the achievement of employees' commitment by means of ensuring quality at work.

At the same time, the fact that companies ensure the existence of an equal opportunities policy for its employees has been seen as a valuable indicator of HRM good practices for the achievement of best results in the Spanish firms. Job design is another human resources practice that allows the building of multi-functional teams. In effect, adequate job design or the existence of an appropriate employee qualification, with respect to the attributed and/or attributable (flexibility) competences, play a fundamental role in the construction of the competitive advantage of the organizations, highly contributing to the improvement of organizational performance.

Training and job stability are also shown as key factors, especially in certain job types that are considered relevant for the future of the organization and for the employees' career plan, together with job design. This included the role that the selection process plays in organizations with high participation and involvement of its employees. As an example, firms usually inform their employees about the economic and financial situation in order to ensure they become involved, committed and cooperative with the common goals of the organization. Hence, communication becomes another important factor in achieving organizational objectives. In this sense, and trying to give a response to our hypothesis of work, our results show that effects derived from HRM practices can be measured by both financial (ROS\& ROA) and subjective indicators (employees, managers', CEOs, perceptions on business results).

In the case of firms from the southern region of Spain, the HR practices have been shown to link in with the employee's commitment, especially in those related to quality processes, the involvement of employees in job design, their participation in work teams, the establishment of equal opportunities policies, permanent training (especially in key job positions), employee selection, and bidirectional communication. All these HR practices have allowed the establishment of competitive advantages for the mentioned firms (Andalucía's firms). Finally, the current research shows how the positive 
effects of human resource management can contribute to business success, benefits that can be witnessed through the perception individuals, work teams, and managers have of the organizations. These benefits seem to be confirmed by financial returns indicators.

\section{LIMITATIONS AND DIRECTIONS FOR FUTURE RESEARCH}

Our conclusions suggest that both the financial and nonfinancial results appear as aspects of a single reality, but do not occur with equal immediacy if targeted in the same direction. This can facilitate future research to analyze the impact of human resources management on business success by means of different statistical techniques. Moreover, it would also be interesting to know which variables moderate the relationship between human resource management practices in relation to business outcomes; in this research they have been directly evaluated, and perhaps in management practice this relationship might not be that direct. It should also be considered as a limitation the non-longitudinal nature of this study, as well as the small size of the sample.

\section{References}

Alcazar, F. M., Fernández, P. M. R., \& Gardey, G. S. (2005). Researching on SHRM: An Analysis of the Debate over the Role Played by Human Resources in Firm Success. Management Review, 116 (2), 213-241.

Arthur, J. B. (1994). Effects of Human Resource Systems on Manufacturing Performance and Turnover. Academy of Management Journal, 37, 670-687.

Aycan, Z. (2005). The Interplay Between Cultural and Institutional/Structural Contingencies in Human Resource Management Practices. International Journal of Human Resource Management, 7, 1083-1119.

Bamberger, P., \& Meshoulam, L. (2000). Human Resource Strategy: Formulation, Implementation and Impact. Thousand Oaks, CA: Sage Publishing.

Barclay, D., Higgins, C., \& Thompson, R. (1995). The Partial Least Squares (PLS) Approach to Causal Modeling: Personal Computer Adoption and Use as an Illustration. Technology Studies, 2(2), 285-309.

Barney, J. B., \& Wright, P. M. (1998). On Becoming a Strategic Partner: the Role of Human Resource in Gaining Competitive Advantage. Human Resource Management, 37(1), 31-46.

Barroso, C., Cepeda, G. A., \& Roldán, J. L. (2010). Applying Maximum Likelihood and PLS on Different Sample Sizes: Studies on SERVQUAL Model and
Employee Behavior Model. In Esposito Vinzi, Chin, Henseler \& Wang (Eds.) Handbook of Partial Least Squares: Concepts, Methods and Applications. New York: Springer.

Basset-Jones, N. (2005). The Paradox of Diversity Management, Creativity and Innovation. Creativity and Management, 14(2), 169-175.

Bontis, N., Hulland , J., \& Crossan, M. M. (2002). Managing an Organizational Learning System by Aligning Stocks and Flows. Journal of Management Studies, 39, 437-469.

Boone, Ch., Van Olffen, W., Van Witteloostuijn, A., \& De Brabander, B. (2004). The Genesis of Top Management Team Diversity: Selective Turnover among Top Management Teams in Dutch Newspaper Publishing, 1970-94. Academy of Management Journal, 47(5), 633-656.

Carpenter, M. A. (2002). The Implications of Strategy and Social Context for the Relationship Between Top Management Team Heterogeneity and Firm Performance. Strategic Management Journal, 23(3), 275-284.

Chin, W. W. (2003). PLS-Graph (Version 03.00, Build 1058) (Computer Software). Texas: University of Houston.

Chin, W. W. (1998). Issues and Opinion on Structural Equation Modeling. MIS Quarterly, 22(1) 7-21. 
Collins, C. J., \& Smith, K. G. (2006). Knowledge Exchange and Combination: the Role of Human Resource Practices in the Performance of High-Technology Firms. Academy of Management Journal, 49(3), 544-560.

Dalrymple, J. F. (2004). Performance Measurement for SME Growth: a Business Profile Benchmarking Approach. Paper presented at the Second World Conference on POM and 15th Annual POM Conference, Cancun, México.

Dess, G. G., \& Davis, P. S. (1984). Porter's (1980) Generic Strategies as Determinants of Strategic Group Membership and Organizational Performance. Academy of Management Journal, 27(3), 467-488.

Eccles, R. (2004). Manifiesto sobre la medida del rendimiento. En Harvard Business Review. Cómo medir el rendimiento en la Empresa. Buenos Aires, Argentina: Grupo Editorial Planeta.

Fornell, C., \& Larcker, D.F. (1981). Evaluating Structural Equation Models with Unobservable Variables and Measurement Error. Journal of Marketing Research, 18, 39-50.

Geisser, S. (1974). A Predictive Approach to the Random Effects Model. Biometrika, 61, 101-107.

Giardini, A., \& Kabst, R. (2008). Effects of Work-Family Human Resource Practices: A Longitudinal Perspective. International Journal of Human Resource Management, 19(11), 2079-2094.

Goll, I., Brown, N., \& Rasheed, A. A. (2008). Top Management Team Demographic Characteristics, Business Strategy, and Firm Performance in the US Airline Industry. Management Decision, 46 (2), 201-222.

González, A., Correa, A. \& Acosta, M. (2002). Factores determinantes de la rentabilidad financiera de las pymes. Revista Española de Financiación y Contabilidad, 31(112), 395-429.

Gonzalez, J. \& Denisi, A. (2009). Cross-level Effects of Demography and Diversity Climate on Organizational Attachment and Firm Effectiveness. Journal of Organizational Behavior, 30. 21-40.

Gooderham, P., Parry, E., \& Ringdal, K. (2008). The Impact of Bundles of Strategic Human Resource Manage- ment Practices on the Performance of European Firms. International Journal of Human Resource Management, 19(11), 2041-2056.

Guest, D. E., Michie. J., \& Conway, M. (2003). Human Resource Management and Corporate Performance in the UK. British Journal of Industrial Relations, 41(2), 291-314.

Guthrie, J. P. (2001). High-involvement Work Practices. Turnover and Productivity: Evidence from New Zealand. Academy of Management Journal, 44(1),180190.

Hartmann, F., Naranjo, D., \& Roldán, J. L. (2005). The Relationship between Leadership Behavior and the Use of Performance Measures: a Test of Antecedents and Consequences. Paper presented at the meeting at the AIMA Conference, Monterey, California.

Martin, F., Romero, P. \& Gardey, G. S. (2006). Modelo explicativo de la influencia de la diversidad sobre el desempeño de los grupos de trabajo. El efecto moderador de la dirección estratégica de los Recursos Humanos. Investigaciones Europeas de Dirección y Economía de la Empresa, 12(1), 225-250.

Mesquita, L. F. \& Lazzarini, S. G. (2008). Horizontal and Vertical Relationships in Developing Economies: Implications for SMEs' Access to Global Markets. Academy of Management Journal, 16(2), 359-380.

Moideenkutty, U., Al-Lamki, A., \& Rama Murthy, Y. S. (2011). HRM Practices and Organizational Performance in Oman. Personnel Review, 40(2), 239 -251.

Naranjo-Gil, D., \& Álvarez-Dardet. C. (2006). El uso del sistema contable de gestión en la implantación de la estrategia: análisis del ajuste contingente. Revista Española de Financiación y Contabilidad, 35(128), 157-179.

Nonaka, I. (1994). A Dynamic Theory of Organizational Knowledge Creation. Organization Science, 1(1), 14-37.

Nunnally, J. (1978). Psychometric Theory. New York: McGraw-Hill.

Real, J. C., Leal, A., \& Roldán, J. L. (2006). Information Technology as a Determinant of Organizational Learning and Technological Distinctive Competencies. Industrial Marketing Management, 35, 505-521. 
Richard, O. C., Murthi, B. P., \& Ismail, K. (2007). Cultural Diversity in Management, Firm Performance and The Moderating Role of Entrepreneurial Orientation. Strategic Management Journal, 28, 1213-1233.

Roberts, N., \& Thatcher, J. (2009). Conceptualizing and Testing Formative Constructs: Tutorial and Annotated Example. The Data Base for Advances in Information Systems, 40(3), 9-39.

SABI (2009). Iberian Annual Review System. Retrieved from $<$ http://sabi.bvdep.com>.

Shahnawaz, M. G., \& Juyal, R. C (2006). Human Resource Management Practices and Organizational Commitment in Different Organizations. Journal of the Indian Academy of Applied Psychology, 32(3), 171178.
Stone, M. (1974). Cross-validatory Choice and Assessment of Statistical Predictions. Journal of the Royal Statistical Society, 36, 111-147.

Tenenhaus, M. (2008). Component-based Structural Equation Modeling. Total Quality Management and Business Excellence, 19(7), 871-886.

Yacuzzi, E. (2010). Herramientas japonesas para la gobernancia de las pequeñas y medianas empresas'. Retrieved from <http://www.educamericas.com/ articulos/reportes-y-papers/herramientas-japonesaspara-la-gobernanza-de-las-pymes $>$.

Zou, S. \& Stan, S. (1998). The Determinants of Export Performance: A Review of the Empirical Literature between 1987 and 1997. International Marketing Review, 15(5), 333-356. 


\section{APPENDIX \\ Scale of Measures}

Likert' scale from 1 to 7

HRM practices

$1=$ In total disagreement and $7=$ In total agreement

Selection (SEL1 .... SEL3)

1) Our company has processes of recruitment and selection that can fill up all available vacancies.

2) As part of the selection process, applicants are informed about the negative aspects of the job.

3) In our company we have developed systems to select personnel (in addition to interviews and / or curriculum analysis).

4) Our company has processes of recruitment and selection that can fill up all available vacancies.

5) As part of the selection process, applicants are informed about the negative aspects of the job.

6) In our company we have developed systems to select personnel (in addition to interviews and / or curriculum analysis).

Training (TRA ... 1... TRA ... 4)

1) Our firm offers training for those considered to be "key positions".

2) All employees receive training for their jobs (without any legal requirement).

3) When employees receive training their performance improves.

4) When employees receive training, it is often relevant for their future / career in the company (job promotions).

Evaluation (EVA1 .... EVA3)

1) Non-management employees are generally measured by a performance appraisal.

2) Non-management employees receive part of their salary based on performance.

3) Normally non-management employees are informed of their performance through information provided by third parties (e.g. superiors, customers, suppliers ...)

Flexible remuneration (FLE1 .... FLE4)

1) Non-management employees are remunerated according to their individual performance

2) Non-management employees are remunerated according to their group performance.

3) Non-management employees have the right to receive monetary incentives.

4) Non-management employees have the right to receive other types of incentives such as profit-sharing, bonuses, recognition...

Job design (JD1 ....JD 7)

1) There is a strong implementation of self-managed or self-directed teams.

2) There is a strong implementation of multi-functional teams.

3) There is a strong presence of "project-based teams".

4) There is a strong implementation of flexi-jobs (flexi-time, online work, videoconferencing, measures to strike balance between work and family life).

5) Most jobs have been designed for employees to optimize their skills and strengths.

6) Most employees are well qualified, or are able to develop new skills.

7) Employees are given the opportunity of changing jobs.

Bidirectional communication (COM1... COM5)

1) The firm provides its employees with regular information about business operations and business behavior.

2) Employees are consulted to know their views and opinions.

3) The firm provides employees with information about the business plan on a regular basis. 
4) The organization has mechanisms to consult employees about plans and future projects of the firm.

5) We consult employee representatives before setting the performance target (individual, group).

Job stability (EST1 .... EST4)

1) Vacancies that require experience are filled by internal promotion.

2) The organization regularly allows internal promotion.

3) The organization is committed to secure job stability.

4) Employees are often made redundant.

Equality (IQUA1)

1) Organization carries out actions to ensure that all employees have equal opportunities

Job quality (CAL1 .... CAL4)

1) The organization gives employees the opportunity to engage in problem-solving situations.

2) The organization has a strong presence of quality circles.

3) The organization facilitates the involvement of its employees in improving teamwork.

4) Employees feel committed when assured the quality of their work.

Organizational Performance (perceived business performance)

Where 1: in total disagreement and 7: in total agreement

Subjective performance (SP)

Individual-level performance

1) Individuals are satisfied working here.

2) Individuals are generally happy working here.

3) Individuals are satisfied with their own performance.

Group-level performance

1) Our group makes a strong contribution to the organization.

2) Our group performs well as a team.

3) Our group meets its performance targets.

Organizational-level performance

1) Our organization is successful.

2) Our organization meets its clients' needs.

3) Our organization's future performance is secure.

4) Our organization is well-respected within the industry. 